\title{
GROWTH RETARDANTS ON DEVELOPMENT AND ORNAMENTAL QUALITY OF POTTED 'LILLIPUT' Zinnia elegans JACQ.
}

\author{
Ana Christina Rossini Pinto ${ }^{1}$; Teresinha de Jesus Deléo Rodrigues ${ }^{2 *}$; Izabel Cristina Leite ${ }^{2}$; \\ José Carlos Barbosa ${ }^{3}$ \\ ${ }^{I}$ UNESP/FCAV - Programa de Pós-Graduação em Produção Vegetal. \\ 2 UNESP/FCAV - Depto. de Biologia Aplicada à Agropecuária, Via de Acesso Prof. Paulo Donato Castellane, s/n- \\ 14884-900 - Jaboticabal, SP - Brasil. \\ ${ }^{3}$ UNESP/FCAV - Depto. de Ciências Exatas. \\ *Corresponding author <tedelro@fcav.unesp.br>
}

ABSTRACT: Zinnias have good potential to be used as flowering, potted plants, being a quick source of novelty for the floriculture industry with the aid of growth retardants. This study evaluated the effect of growth retardants on development and production of short, compact and attractive plants of potted 'Lilliput' Zinnia elegans, a highly ornamental zinnia with low cost seeds. Trials were set up in randomized blocks, with ten treatments (control and three treatments of each retardant: daminozide, paclobutrazol and chlormequat) and four replications (two pots per experimental unit, with one plant per 0.6-L pot). Paclobutrazol $(0.5,0.75$ and $1.0 \mathrm{mg}$ a.i. per pot) and chlormequat $\left(1.0,2.0\right.$ and $\left.3.0 \mathrm{~g} \mathrm{~L}^{-1}\right)$ were applied as a single drench $(40 \mathrm{~mL}$ per pot), and daminozide $\left(2.5,3.75\right.$ and $\left.5.0 \mathrm{~g} \mathrm{~L}^{-1}\right)$ as a single foliar spray to runoff $(10 \mathrm{~mL}$ per pot $)$, at apical flower bud stage. Daminozide $\left(2.5\right.$ and $\left.3.75 \mathrm{~g} \mathrm{~L}^{-1}\right)$, paclobutrazol $(0.5,0.75$ and $1.0 \mathrm{mg}$ a.i. per pot) and chlormequat at $1.0 \mathrm{~g} \mathrm{~L}^{-1}$ significantly reduced plant height and side branches length, without affecting flower diameter, delaying production cycle and causing phytotoxicity symptoms. However, plants were not short and compact enough to meet market quality demand. Chlormequat $\left(2.0\right.$ and $\left.3.0 \mathrm{~g} \mathrm{~L}^{-1}\right)$ caused phytotoxicity symptoms and daminozide $\left(5.0 \mathrm{~g} \mathrm{~L}^{-1}\right)$ delayed production cycle.

Key words: floriculture, daminozide, paclobutrazol, chlormequat, flowering

\section{RETARDADORES DE CRESCIMENTO NO DESENVOLVIMENTO E NA QUALIDADE ORNAMENTAL DE Zinnia elegans JACQ. 'LILLIPUT' ENVASADA}

\begin{abstract}
RESUMO: As zínias têm grande potencial como plantas floríferas envasadas e representam rápida fonte de novidade para a floricultura com o auxílio de retardadores de crescimento. Avaliaram-se os efeitos de retardadores de crescimento no desenvolvimento e na produção de plantas envasadas de porte baixo, compactas e atrativas de 'Lilliput' Zinnia elegans, cultivar altamente ornamental, com sementes de baixo custo. O delineamento experimental foi em blocos casualizados, com dez tratamentos (controle e três concentrações de cada retardador: daminozide, paclobutrazol e chlormequat) e quatro repetições (dois vasos por unidade

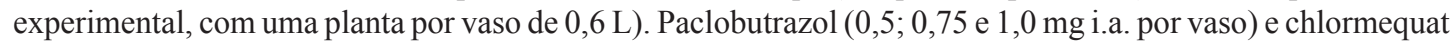
$\left(1,0 ; 2,0\right.$ e $\left.3,0 \mathrm{~g} \mathrm{~L}^{-1}\right)$ foram aplicados ao substrato ( $40 \mathrm{~mL}$ por vaso), enquanto o daminozide $(2,5 ; 3,75$ e 5,0 $\left.\mathrm{g} \mathrm{L}^{-1}\right)$ foi aplicado através de pulverização foliar $(10 \mathrm{~mL}$ por vaso), no estádio de gema floral apical visível. Daminozide $\left(2,5\right.$ e 3,75 $\left.\mathrm{g} \mathrm{L}^{-1}\right)$, paclobutrazol $\left(0,5 ; 0,75\right.$ e $1,0 \mathrm{mg}$ i.a. por vaso) e $1,0 \mathrm{~g} \mathrm{~L}^{-1}$ de chlormequat reduziram significativamente a altura das plantas e o comprimento dos ramos laterais, sem afetar o diâmetro dos capítulos, atrasar o ciclo de produção e causar fitotoxicidade. Entretanto, as plantas não se apresentaram suficientemente baixas e compactas para atender às exigências de qualidade do mercado. Chlormequat $(2,0 \mathrm{e}$ 3,0 $\left.\mathrm{g} \mathrm{L}^{-1}\right)$ causou fitotoxicidade e daminozide $\left(5,0 \mathrm{~g} \mathrm{~L}^{-1}\right)$ aumentou o ciclo de produção.

Palavras-chave: floricultura, daminozide, paclobutrazol, chlormequat, florescimento
\end{abstract}

\section{INTRODUCTION}

Zinnias are well known garden plants and cut flowers in Brazil, and can also be used as flowering potted plant. They have attractive capitula with a wide variety of colors, shape and size, long bloom period, drought tolerance, easy propagation, fast growth, minimal labor requirements, rusticity, and are a quick source of novelty for the floriculture industry with the aid of growth retardants (Pinto, 2003).

Zinnia elegans 'Lilliput' is a dwarf, short garden plant (31.0 to $46.0 \mathrm{~cm}$ in height) (Metcalf \& Sharma, 
1971). It blooms a wide variety of brightly, bi-colored ray florets and a highly double-flowered capitula type, which increase its ornamental value compared to single and semi-double zinnia type capitula (Miyajima \& Nakayama, 1994). Studies on production of zinnias as potted plants showed that 'Lilliput' was not short and compact enough to produce high-quality, marketable plants without the aid of growth retardants (Pinto, 2003), commonly used to produce short and attractive compact floriferous plants (Andersen \& Andersen, 2000).

Studies on the effect of growth retardants on Zinnia elegans cultivars are only a few (Armitage et al., 1981; Banko \& Stefani, 1988; Cox \& Keever, 1988; Latimer, 1991; Kim et al., 1992; Chen et al., 1993), none of them done with 'Lilliput'. Effects of growth retardants on Zinnia elegans have not been previously studied in Brazil. Differences in responsiveness to growth retardants may be found among cultivars and can depend on environmental and cultural growing conditions (Grzesik, 1989). The objective of this study was to evaluate the effects of growth retardants on development and ornamental characteristics of potted zinnia 'Lilliput', aiming to produce short and attractive compact plants.

\section{MATERIAL AND METHODS}

Plants were grown in the Fall of 2001, in a polyethylene-covered greenhouse, in Jaboticabal, SP, Brazil ( $21^{\circ} 15^{\prime} 22^{\prime \prime} \mathrm{S}, 48^{\circ} 15^{\prime} 18^{\prime \prime} \mathrm{W}$; altitude $\left.610 \mathrm{~m}\right)$. Seeds of 'Lilliput' Zinnia elegans were sown on polystyrene plug trays (model CM 128-62), filled with commercial media and transplanted to 0.6 - $\mathrm{L}$ black plastic pots $(9.4 \mathrm{~cm}$ deep; $13.0 \mathrm{~cm}$ wide), when second nodal leaves were fully expanded. Each pot was filled with commercial growing media: composted pine and eucalyptus bark, composted tree fern fiber dust, washed coconut dust, sterilized rice shell, turf, crushed vegetal charcoal, vermiculite and clay $\left(\mathrm{pH}_{\text {water }}\right.$ 6.12; E.C. 0.75), fertilized with Osmocote Sierra ${ }^{\circledR}$ 15-10-10 + micro (1.08 g per pot).

Plants were kept under natural photoperiod $(11 \mathrm{~h}$ $56^{\prime}$ to $11 \mathrm{~h}$ ); greenhouse temperatures ranged from $8.0 \pm$ $1{ }^{\circ} \mathrm{C}$ (minimum) to $40.0 \pm 1{ }^{\circ} \mathrm{C}$ (maximum), average temperature $26.0 \pm 1{ }^{\circ} \mathrm{C}$. Daily relative humidities ranged from $36 \%$ (minimum) to $99 \%$ (maximum). Mean maximum photosynthetic photon flux inside the greenhouse was 509.6 $\mu \mathrm{mol} \mathrm{m} \mathrm{m}^{-2} \mathrm{~s}^{-1}$. All pots received the same amount of water.

Trials were set up in complete randomized blocks, with ten treatments (control and three concentrations of each retardant: daminozide, paclobutrazol and chlormequat) and four replications (two pots per experimental unit, with one plant per pot). Paclobutrazol (0.5, 0.75 and $1.0 \mathrm{mg}$ a.i. per pot, respectively $0.0125,0.0188$ and $0.0250 \mathrm{~g} \mathrm{~L}^{-1}$ ) and chlormequat (1.0, 2.0 and $\left.3.0 \mathrm{~g} \mathrm{~L}^{-1}\right)$ were applied as a single drench $(40 \mathrm{~mL}$ per pot), and daminozide $\left(2.5,3.75\right.$ and $\left.5.0 \mathrm{~g} \mathrm{~L}^{-1}\right)$ as a single, uniform foliar spray to runoff ( $10 \mathrm{~mL}$ per pot). Control plants were sprayed with deionized water (10 $\mathrm{mL}$ per pot). Freshlyprepared aqueous solutions of the retardants were applied 28 days after sowing when apical flower bud presented 3-5 $\mathrm{mm}$ and plants were $17.0 \mathrm{~cm}$ tall, at late afternoon (relative humidity: 35 - $45 \%$, temperature: $31.0-27.0 \pm$ $\left.1{ }^{\circ} \mathrm{C}\right)$. At this developmental stage, 'Lilliput' shows major growth, mainly of side branches (Pinto, 2003).

Main stem height (from main stem base to inflorescence receptacle insertion), internode length, number of nodes, side branches length and total leaf area were measured at the end of production cycle (six to seven open inflorescences per plant). Total leaf area was estimated by taking a sample of 20 leaves from each experimental unit, measured with a Digital Image Analysis System, Delta T Devices. Total leaf area was determined by proportion, using the dry mass value of measured leaves.

Green, senescent and dead leaves (more than two thirds of the lamina midrib yellow or dried), main stem, side branches, inflorescences, floral buds and roots were isolated and dried at $75^{\circ} \mathrm{C}$ in a forced-air oven to determine dry mass $(\mathrm{g})$. Foliage and inflorescences harvest index $[$ FIHI $=$ (leaves dry mass + inflorescences dry mass $)$ / plant total dry mass], leaf mass ratio (LMR = leaves dry mass/ plant total dry mass) and inflorescence harvest index $(\mathrm{IHI}=$ inflorescences dry mass/ plant total dry mass $)$ were recorded (Daie, 1985; Pereira \& Machado, 1987).

Production cycle was established considering the number of days from sowing to six or seven opened inflorescences. Opened inflorescence was considered when ray florets petals were fully expanded, and tubular florets opened. To evaluate plant quality, inflorescence diameter, plant height and plant spread diameter (major width from one tip to the other of foliage canopy) were measured.

Data were subjected to analysis of variance (ANOVA) and to Tukey's multiple range test. Regression analysis was determined to establish the concentration response curves of growth retardants (control data included in regression analysis). Polynomial regression analyses were performed for all evaluated parameters.

\section{RESULTS AND DISCUSSION}

Chlormequat drench at 2.0 and $3.0 \mathrm{~g} \mathrm{~L}^{-1}$ caused a slightly visible wilt (Figure 1-A), $15 \mathrm{~h}$ after application. Pale green aqueous lesions were observed on leaf lamina margins $24 \mathrm{~h}$ after application (Figure 1-B), followed by foliar chlorosis on leaf margins and center, which persisted during production period $\left(2.0 \mathrm{~g} \mathrm{~L}^{-1}\right)$, making plants unsuitable for marketing. Plants treated with chlormequat at $3.0 \mathrm{~g} \mathrm{~L}^{-1}$ developed severe foliar chlorosis and necrosis (Figure 1-C), leading to plants death. 'Lilliput' was sensitive to chlormequat concentrations in the range of 2.0 to $3.0 \mathrm{~g} \mathrm{~L}^{-1}$. However, Cathey (1975) reported that concentration ranging on 0.5 to $3.0 \mathrm{~g} \mathrm{~L}^{-1}$ were 
inactive to 'Yellow Zenith' Z. elegans. No visual, phytotoxic symptoms were observed on plants treated with 1.0 $\mathrm{g} \mathrm{L}^{-1}$ of chlormequat other than thicker roots compared to control (Figure 1-D and Figure 1-E).

Plants treated with paclobutrazol showed darker green leaves in comparison to control, daminozide and chlormequat $\left(1.0 \mathrm{~g} \mathrm{~L}^{-1}\right)$ treated plants. This is a common effect for paclobutrazol-treated plants as a result of either increasing chlorophyll biosynthesis and/or reduction of leaf expansion accompanied by normal rates of chlo- rophyll biosynthesis (Davis et al., 1988; Halmann, 1990). There were no apparent effects of daminozide, paclobutrazol and chlormequat $\left(1.0 \mathrm{~g} \mathrm{~L}^{-1}\right)$ on inflorescence color and shape.

At the end of production cycle, treated plants were shorter than control plants. Main stem height suppression was related to shorter internode elongation and not to a decrease in node number (Table 1). Internode length and main stem height responded quadratically to daminozide treatment, but showed a negative linear re-

Table 1 - Effects of growth retardants on main stem internode length, height and number of nodes, side branches length, plant height and spread diameter of 'Lilliput' plants, at the end of the production cycle.

\begin{tabular}{|c|c|c|c|c|c|c|}
\hline \multirow{2}{*}{ Treatment } & \multicolumn{3}{|c|}{ Main stem } & \multirow{2}{*}{$\begin{array}{l}\text { Side branches } \\
\text { length }\end{array}$} & \multicolumn{2}{|r|}{ Plant } \\
\hline & Internode length & Height & No. of nodes & & Height & Spread diameter \\
\hline & 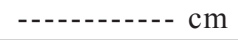 & 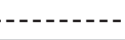 & & - & $--\mathrm{cm}-$. & - \\
\hline Control & $6.51 \mathrm{a}$ & $51.63 \mathrm{a}$ & $7.25 \mathrm{a}$ & $30.56 \mathrm{a}$ & $69.29 \mathrm{a}$ & $29.50 \mathrm{a}$ \\
\hline $2.50 \mathrm{~g} \mathrm{~L}^{-1}$ daminozide & $4.40 \mathrm{~b}$ & $34.70 \mathrm{~b}$ & $7.13 \mathrm{a}$ & $18.51 \mathrm{c}$ & $50.75 \mathrm{c}$ & $26.38 \mathrm{a}$ \\
\hline $3.75 \mathrm{~g} \mathrm{~L}^{-1}$ daminozide & $4.63 \mathrm{~b}$ & $38.76 \mathrm{~b}$ & $7.38 \mathrm{a}$ & $21.22 \mathrm{bc}$ & $54.56 \mathrm{bc}$ & 29.44 a \\
\hline $5.00 \mathrm{~g} \mathrm{~L}^{-1}$ daminozide & $4.96 \mathrm{~b}$ & $38.46 \mathrm{~b}$ & $6.88 \mathrm{a}$ & $19.53 \mathrm{bc}$ & $53.39 \mathrm{bc}$ & $27.94 \mathrm{a}$ \\
\hline $0.50 \mathrm{mg}$ a.i. paclobutrazol & $5.00 \mathrm{~b}$ & $41.74 \mathrm{~b}$ & $7.38 \mathrm{a}$ & $26.95 \mathrm{ab}$ & $63.53 \mathrm{ab}$ & $28.63 \mathrm{a}$ \\
\hline $0.75 \mathrm{mg}$ a.i. paclobutrazol & $4.63 \mathrm{~b}$ & $37.59 \mathrm{~b}$ & $7.25 \mathrm{a}$ & $22.46 \mathrm{bc}$ & $54.48 \mathrm{bc}$ & $27.94 \mathrm{a}$ \\
\hline $1.00 \mathrm{mg}$ a.i. paclobutrazol & $4.63 \mathrm{~b}$ & $36.99 \mathrm{~b}$ & $7.38 \mathrm{a}$ & $19.50 \mathrm{bc}$ & $48.39 \mathrm{c}$ & $25.11 \mathrm{a}$ \\
\hline $1.00 \mathrm{~g} \mathrm{~L}^{-1}$ chlormequat & $4.82 \mathrm{~b}$ & $36.45 \mathrm{~b}$ & $6.63 \mathrm{a}$ & $15.27 \mathrm{c}$ & $42.09 \mathrm{c}$ & $24.63 \mathrm{a}$ \\
\hline Mean & 4.95 & 39.54 & 7.16 & 21.75 & 54.56 & 27.44 \\
\hline Ftest ${ }_{\text {treatment }}$ & $8.35 * *$ & $10.61 * *$ & $1.47 \mathrm{~ns}$ & $9.14 * *$ & $10.29 * *$ & $1.73 \mathrm{~ns}$ \\
\hline HSD (Tukey's test) & 1.09 & 7.71 & 1.07 & 7.69 & 12.58 & 6.76 \\
\hline Coefficient of variation (\%) & 9.25 & 8.21 & 6.31 & 14.90 & 9.72 & 10.39 \\
\hline
\end{tabular}

Mean separation within columns by Tukey's multiple range test, $5 \%$ level; HSD $=$ honestly significant difference; ${ }^{\text {ns }}$ nonsignificant at $(P>$ $0.05) ;{ }^{* *}$ difference at $(P<0.01)$.

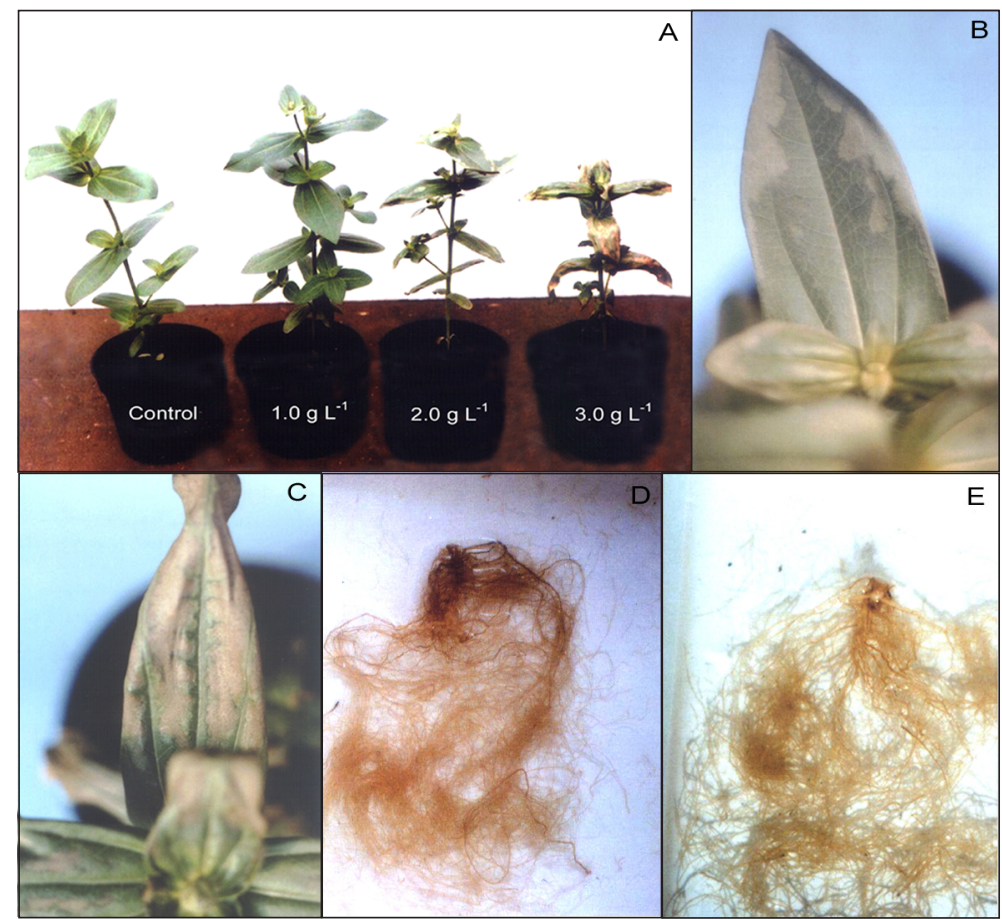

Figure 1 - A) 'Lilliput' control and chlormequat treated plants $\left(1.0 ; 2.0\right.$ and $\left.3.0 \mathrm{~g} \mathrm{~L}^{-1}\right)$; B) Pale green aqueous lesions on 'Lilliput' leaf lamina margin treated with chlormequat $\left(2.0 \mathrm{~g} \mathrm{~L}^{-1}\right)$; C) Severe leaf burning and necrosis on 'Lilliput' leaf lamina treated with chlormequat (3.0 $\left.\mathrm{g} \mathrm{L}^{-1}\right)$; D) 'Lilliput' control plants root system; E) Root system with thicker roots of 'Lilliput' treated plant with chlormequat $\left(1.0 \mathrm{~g} \mathrm{~L}^{-1}\right)$. 
sponse to increasing concentrations of paclobutrazol (Figure 2). Minimum internode length of $4.40 \mathrm{~cm}$ for $3.24 \mathrm{~g}$ $\mathrm{L}^{-1}$ of daminozide and minimum main stem height of $35.78 \mathrm{~cm}$ for $3.35 \mathrm{~g} \mathrm{~L}^{-1}$ of daminozide can be predicted from the models. Regression analysis of node number and daminozide and paclobutrazol treatments were not significant (data not shown).

Growth retardants, except paclobutrazol at $0.5 \mathrm{mg}$ a.i. per pot, reduced side branches length and plant height (Table 1). Side branches length and plant height responded quadratically to daminozide treatments but showed a negative linear response to increasing concentration of paclobutrazol (Figure 2). Minimum side branches length of $18.98 \mathrm{~cm}$ for $3.71 \mathrm{~g} \mathrm{~L}^{-1}$ of daminozide, and minimum plant height of $51.50 \mathrm{~cm}$ for $3.53 \mathrm{~g} \mathrm{~L}^{-1}$ of daminozide, can be predicted from the models (Figure 2).

Banko \& Stefani (1988) found that daminozide spray $\left(5.0 \mathrm{~g} \mathrm{~L}^{-1}\right)$ reduced internode length and plant height of 'Yellow Marvel' Z. elegans. Daminozide sprays also presented similar results on 'Lilliput', but at lower concentrations (2.5 and $\left.3.75 \mathrm{~g} \mathrm{~L}^{-1}\right)$. Banko \& Stefani (1988) reported also that paclobutrazol drench $(0.15 \mathrm{mg}$ a.i. per pot) had no effect on zinnia growth suppression, requiring higher rates of this compound. In this study, paclobutrazol drench at higher rates $(0.5,0.75$ and $1.0 \mathrm{mg}$ a.i. per pot) resulted in shorter plants with shorter internodes. Cox \& Keever (1988) also observed height reduc-

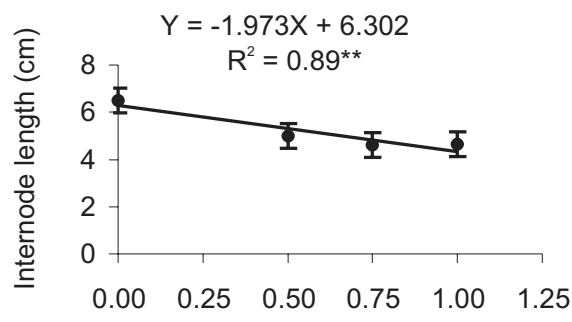

B Paclobutrazol (mg a.i. per pot)
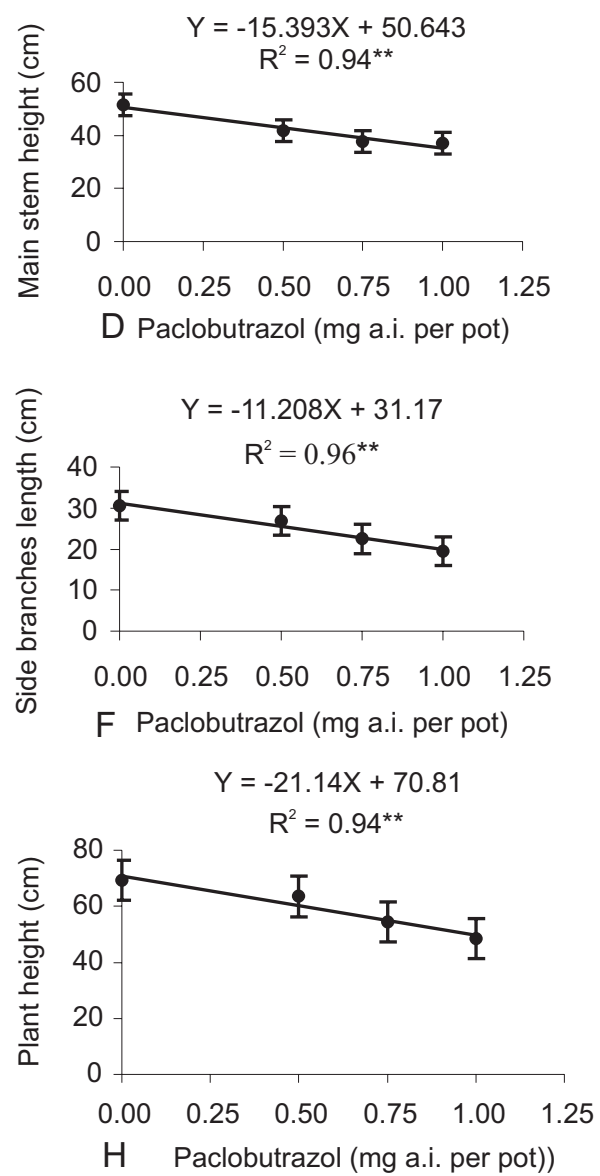

Figure 2 - Regression models of daminozide and paclobutrazol effects on internode length (A-B), main stem height (C-D), side branches length (E-F) and plant height $(\mathrm{G}-\mathrm{H})$ of 'Lilliput', at the end of production cycle. Vertical bars represent the standart error of mean, $\mathrm{n}=4$; ${ }^{*}$ significant difference at $(P<0.05)$; ${ }^{* *}$ significant difference at $(P<0.01)$. 
tions of 'Scarlet Ruffles' Z. elegans with paclobutrazol drenches in the range of 0.5 and $1.0 \mathrm{mg}$ a.i. per pot.

One application of paclobutrazol at higher concentrations should be tested, once the polynomial regression analysis for main stem height, internode length, plant height and side branches length showed a negative linear response to the studied concentrations (Figure 2). Plant spread diameter was not affected by growth retardants (Table 1). Plants were too spread (Figure 3). Christensen $\&$ Friis (1987) reported that a spread diameter of $20.0 \mathrm{~cm}$ would be satisfactory for many flowering potted plants.

Number of leaves and total leaf area were not affected by retardants application, and the regression analysis for these parameters and growth retardants concentra- tions were not significant (data not shown). Number of leaves of Z. elegans is related to plant's node number (usually, a maximum of two leaves develop at each node). Therefore, when retardants suppress internode elongation without changing the node number, no effect is observed in the number of plant leaves. Although inhibition of gibberellin biosynthesis by growth retardants may rapidly reduce stem elongation, leaf initiation may not be affected if retardants reduce subapical meristematic activity without concomitant disruption of apical meristematic function (Sachs \& Hackett, 1972).

Growth retardants altered 'Lilliput' dry mass distribution pattern without changing plant total dry mass (Table 2). Plants treated with daminozide $\left(3.75 \mathrm{~g} \mathrm{~L}^{-1}\right)$,

Table 2 - Effects of growth retardants on dry mass (g) of 'Lilliput', at the end of the production cycle.

\begin{tabular}{|c|c|c|c|c|c|c|c|c|}
\hline Treatment & $\begin{array}{l}\text { Green } \\
\text { leaves }\end{array}$ & $\begin{array}{l}\text { Senescent and } \\
\text { dead leaves* }\end{array}$ & Main stem & $\begin{array}{c}\text { Side } \\
\text { branches }\end{array}$ & Inflorescences & $\begin{array}{l}\text { Floral } \\
\text { buds* }\end{array}$ & Roots & Total \\
\hline & $---\cdot--$ & & & $-\%--$ & - & $-\cdots--$ & ---- & g \\
\hline Control & $22.4 \mathrm{~b}$ & $1.7 \mathrm{a}$ & $20.1 \mathrm{a}$ & $29.2 \mathrm{a}$ & $21.3 \mathrm{a}$ & $1.9 \mathrm{a}$ & $5.0 \mathrm{a}$ & $5.84 \mathrm{a}$ \\
\hline $2.50 \mathrm{~g} \mathrm{~L}^{-1}$ daminozide & $24.9 \mathrm{ab}$ & $1.8 \mathrm{a}$ & $16.8 \mathrm{~b}$ & $23.6 \mathrm{bcd}$ & $24.7 \mathrm{a}$ & $2.0 \mathrm{a}$ & $6.3 \mathrm{a}$ & $5.38 \mathrm{a}$ \\
\hline $3.75 \mathrm{~g} \mathrm{~L}^{-1}$ daminozide & $27.6 \mathrm{a}$ & $1.7 \mathrm{a}$ & $18.0 \mathrm{ab}$ & $23.7 \mathrm{bcd}$ & $22.6 \mathrm{a}$ & $1.9 \mathrm{a}$ & $5.9 \mathrm{a}$ & $5.70 \mathrm{a}$ \\
\hline $5.00 \mathrm{~g} \mathrm{~L}^{-1}$ daminozide & $25.8 \mathrm{ab}$ & $1.7 \mathrm{a}$ & $17.3 \mathrm{ab}$ & $22.7 \mathrm{bcd}$ & $25.4 \mathrm{a}$ & $2.0 \mathrm{a}$ & $6.0 \mathrm{a}$ & $5.70 \mathrm{a}$ \\
\hline $0.50 \mathrm{mg}$ a.i. paclobutrazol & $25.0 \mathrm{ab}$ & $1.6 \mathrm{a}$ & $17.5 \mathrm{ab}$ & $27.5 \mathrm{ab}$ & $22.0 \mathrm{a}$ & $1.9 \mathrm{a}$ & $6.3 \mathrm{a}$ & $5.50 \mathrm{a}$ \\
\hline $0.75 \mathrm{mg}$ a.i. paclobutrazol & $26.2 \mathrm{ab}$ & $1.6 \mathrm{a}$ & $17.5 \mathrm{ab}$ & $24.8 \mathrm{abc}$ & $23.5 \mathrm{a}$ & $1.9 \mathrm{a}$ & $5.8 \mathrm{a}$ & $4.93 \mathrm{a}$ \\
\hline $1.00 \mathrm{mg}$ a.i. paclobutrazol & $27.0 \mathrm{a}$ & $1.7 \mathrm{a}$ & $18.4 \mathrm{ab}$ & $21.5 \mathrm{~cd}$ & $24.8 \mathrm{a}$ & $1.9 \mathrm{a}$ & $6.1 \mathrm{a}$ & $4.79 \mathrm{a}$ \\
\hline $1.00 \mathrm{~g} \mathrm{~L}^{-1}$ chlormequat & $27.4 \mathrm{a}$ & $1.6 \mathrm{a}$ & $17.4 \mathrm{ab}$ & $18.8 \mathrm{~d}$ & $27.2 \mathrm{a}$ & $2.1 \mathrm{a}$ & $6.3 \mathrm{a}$ & $4.84 \mathrm{a}$ \\
\hline Mean & 25.8 & 1.7 & 17.9 & 24.0 & 23.9 & 1.9 & 6.0 & 5.34 \\
\hline $\mathrm{F}$ test ${ }_{\text {treatment }}$ & $4.17 * *$ & $1.23^{\mathrm{ns}}$ & $2.19^{\mathrm{ns}}$ & $8.36 * *$ & $1.24^{\mathrm{ns}}$ & $1.07^{\mathrm{ns}}$ & $0.52^{\mathrm{ns}}$ & $1.78^{\mathrm{ns}}$ \\
\hline HSD (Tukey's test) & 3.99 & 0.21 & 3.26 & 5.39 & 8.36 & 0.33 & 2.81 & 1.50 \\
\hline C.V (\%) & 6.54 & 5.20 & 7.70 & 9.47 & 14.73 & 7.09 & 19.83 & 11.87 \\
\hline
\end{tabular}

Mean separation within columns by Tukey's multiple range test, $5 \%$ level; HSD = honestly significant difference; C.V $=$ coefficient of variation; ${ }^{\text {ns }}$ nonsignificant at $(P>0.05) ;{ }^{* *}$ difference at $(P<0.01) ;$ data converted to $\ln (\mathrm{x}+5.0)$, for analysis and presentation.
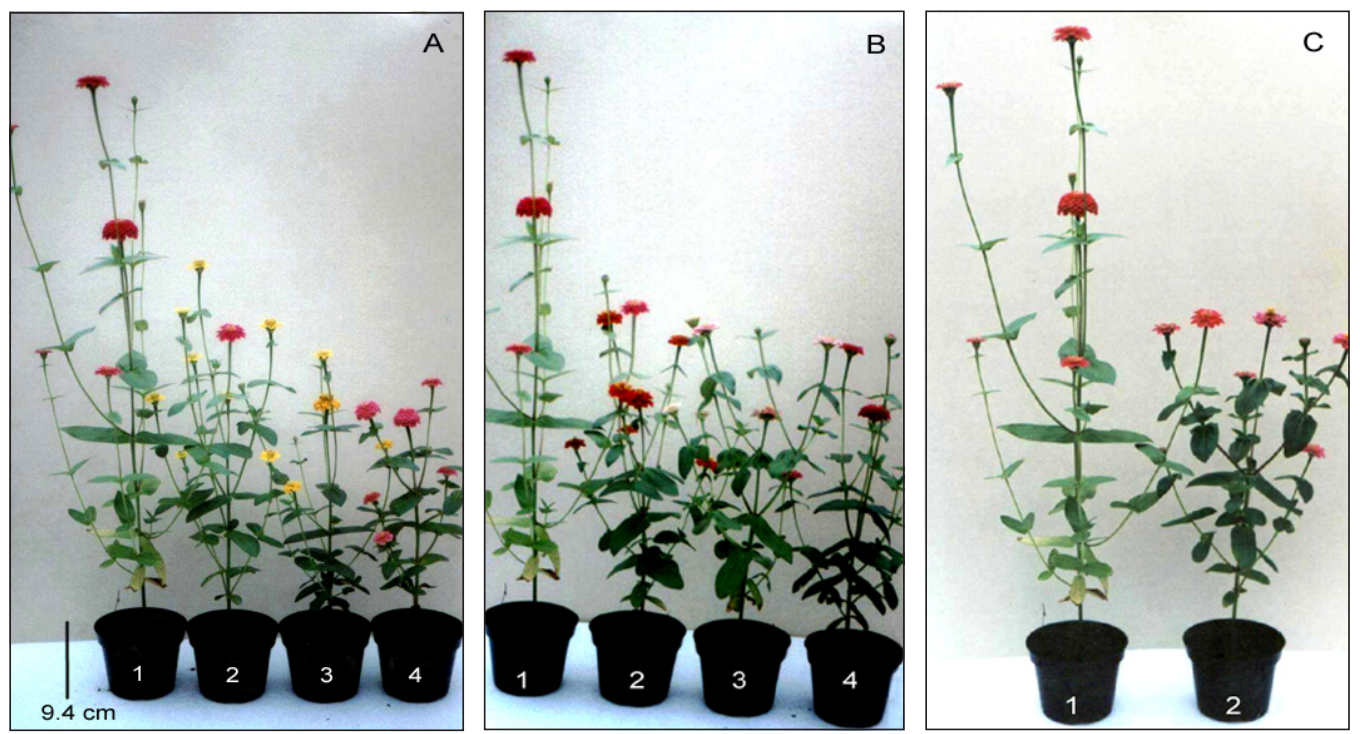

Figure 3 - Effects of paclobutrazol (A: 1 - control; 2 - $0.5 \mathrm{mg}$ a.i. per pot; 3 - $0.75 \mathrm{mg}$ a.i. per pot; 4 - $1.0 \mathrm{mg}$ a.i. per pot), daminozide (B: 1- control; 2 - $2.5 \mathrm{~g} \mathrm{~L}^{-1} ; 3$ - $3.75 \mathrm{~g} \mathrm{~L}^{-1} ; 4$ - $\left.5.0 \mathrm{~g} \mathrm{~L}^{-1}\right)$ and chlormequat (C: 1- control; 2 - $1.0 \mathrm{~g} \mathrm{~L}^{-1}$ ) on plant height of Zinnia elegans 'Lilliput', at the end of production cycle. 
paclobutrazol (1.0 mg a.i. per pot) and chlormequat (1.0 $\mathrm{g} \mathrm{L}^{-1}$ ) had greater green leaves dry mass and smaller side branches dry mass, compared to control plants. Only 2.5 $\mathrm{g} \mathrm{L}^{-1}$ daminozide-treated plants showed a reduction in main stem dry mass.

There was linear increase in green leaves dry mass and a linear decrease in side branches dry mass, with increasing daminozide and paclobutrazol concentrations. Daminozide also conditioned linear decrease in main stem dry mass and a linear increase in inflorescences dry mass. Increasing paclobutrazol concentration provided a linear increase in root dry mass (Figure 4).
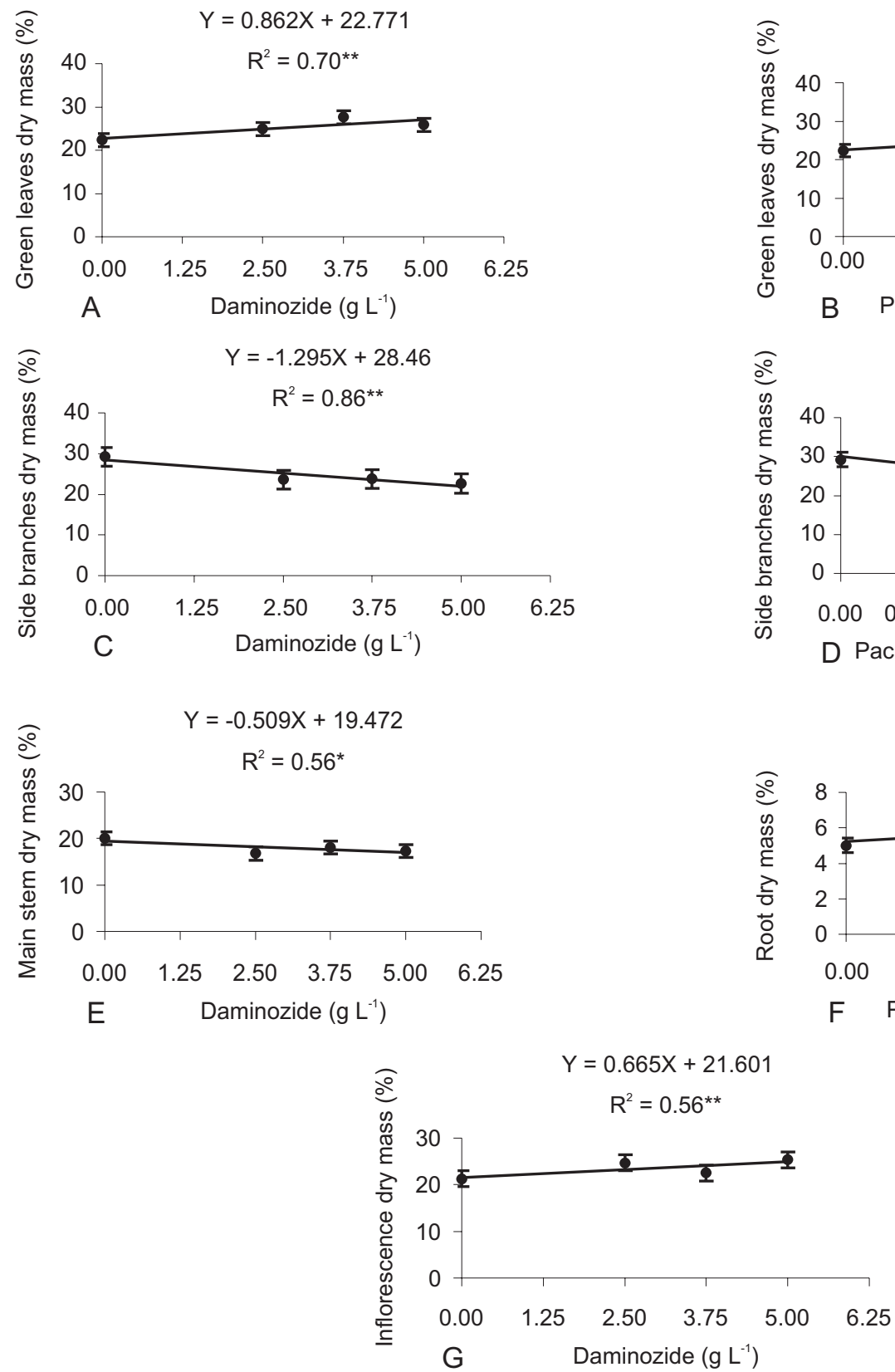

Figure 4 - Regression models of daminozide and paclobutrazol effects on green leaves (A-B), side branches (C-D), main stem (E), root (F) and inflorescence $(\mathrm{G})$ dry mass of 'Lilliput', at the end of production cycle. Vertical bars represent the standart error of mean, $\mathrm{n}=4 ;$ *significant difference at $(P<0.05) ; * *$ significant difference at $(P<0.01)$.

Daminozide and paclobutrazol strongly reduced sink activity in side branches, leading to assimilate retention on leaves. Growth retardants could reduce sink activity in stems while increases in roots and inhibit assimilated ${ }^{13} \mathrm{C}$ translocation from leaves to others zinnia organs (Kim \& Suzuki, 1989). Hence, branches translocation is more restricted compared to roots. Roots growth is less affected, or could also increase, by retardants application (Latimer, 1991). Some authors suggested that gibberellin promotes the increase of sink activity or rates of phloem unloading in the stems, but does not affect assimilate production or phloem loading at the source (Lovell, 1971; Mulligan \& Patrick, 1979).
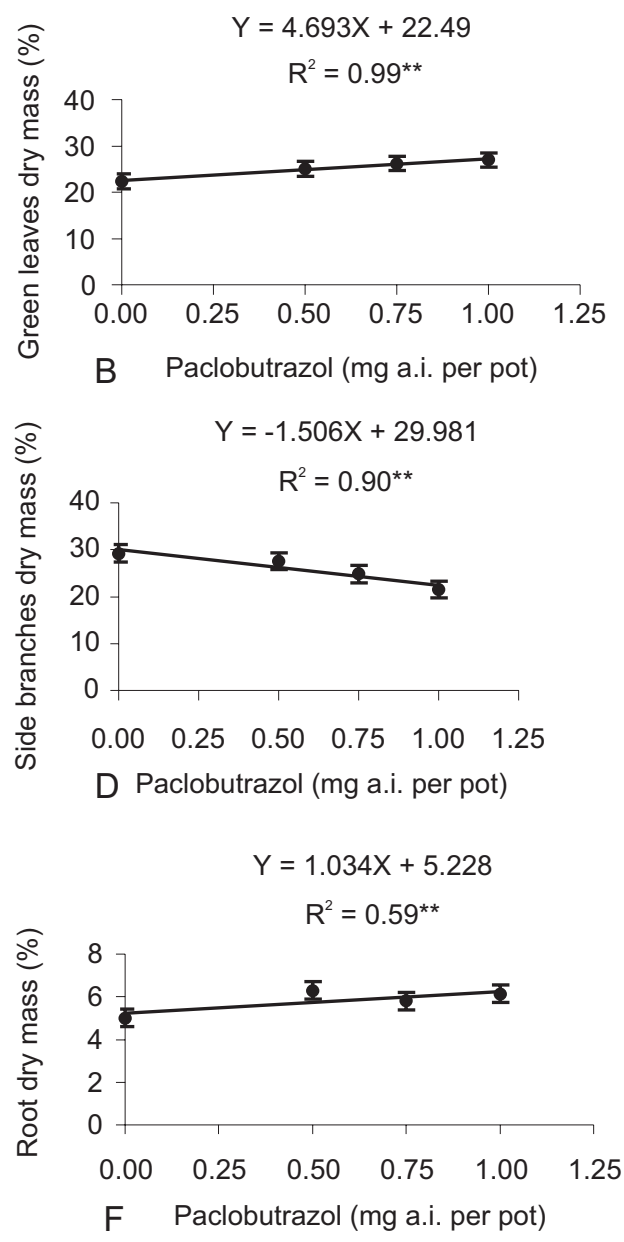
Plants treated with daminozide $\left(3.75 \mathrm{~g} \mathrm{~L}^{-1}\right)$, paclobutrazol (1.0 $\mathrm{mg}$ a.i. per pot) and chlormequat (1.0 $\mathrm{g} \mathrm{L}^{-1}$ ) had higher leaf mass ratio compared to control (Table 3). There was linear increase in leaf mass ratio with increasing paclobutrazol and daminozide concentrations (Figure 5), that is, retardants might have induced an assimilate retention on the leaves.

Daminozide (5.0 $\left.\mathrm{g} \mathrm{L}^{-1}\right)$, paclobutrazol (1.0 mg a.i. per pot) and chlormequat $\left(1.0 \mathrm{~g} \mathrm{~L}^{-1}\right)$ increased foliage and inflorescence harvest index (Table 3 ), with a positive, linear response to increasing concentrations of daminozide and paclobutrazol (Figure 5). Although inflorescences harvest index did not differ among control and retardant treatments (Table 3), a linear increase was observed in inflorescences harvest index with increasing daminozide concentrations (Figure 5). This seems to indicate that paclobutrazol induces the conversion of photosynthesis products only in foliage, once no significant tendency was observed between inflorescences harvest index and paclobutrazol concentrations (data not shown). At any rate, daminozide leads to a conversion of photosynthesis products to foliage and inflorescences, once a linear increase in inflorescences harvest index with increasing daminozide concentrations was observed (Table 3). Thus, daminozide tends to promote the translocation of photosynthates also to the inflorescences, which will contribute to improve plant quality, since for potted plants, the harvest products of economic importance are foliage and inflorescences.

'Lilliput' inflorescence diameter was not affected by growth retardants (Table 3 ), and regression analysis for inflorescence diameter and retardants concentrations were not significant (data not shown). However, Armitage et al. (1981) observed reduction on inflorescence diam- eter of Z. elegans cultivars as the number of daminozide (5.0 $\left.\mathrm{g} \mathrm{L}^{-1}\right)$ applications increased. Chen et al. (1993) recorded that a single foliar application of paclobutrazol $\left(0.25\right.$ or $\left.0.75 \mathrm{~g} \mathrm{~L}^{-1}\right)$ reduced inflorescence diameter of potted 'Sunrise Yellow' Z. elegans. The number of application (1, 2, 3 and 4 times in the case of daminozide), differences in environmental conditions, cultivars sensibility to retardants, and method of application (spray or drench) may explain these contrastant results.

Daminozide $\left(5.0 \mathrm{~g} \mathrm{~L}^{-1}\right)$ delayed production cycle (Table 3), with a positive linear response to increasing concentrations of daminozide (Figure 5). Daminozide delayed inflorescence development (data not shown). Armitage et al. (1981) and Latimer (1991) also found that daminozide at $5.0 \mathrm{~g} \mathrm{~L}^{-1}$ delayed flowering time in other Z. elegans cultivars. Flowering delay after daminozide application could derive from a blockage of gibberellin biosynthesis or from a wholly or partly restriction in action of one or more active endogenous gibberellins, which may be flowering promoters. Growth retardants action can be relatively specific for each giberellin (Koranski et al., 1979). Thus, growth retardant could decrease the synthesis of gibberellin, that promote main stem and side branches elongation and, simultaneously, promote or inhibit the synthesis of gibberellin, that promote flowering.

Although growth retardants reduced 'Lilliput' internode length, main stem height, side branches and plant height (Table 1), plants were not short and compact enough to meet market quality standards. Considering the pot size used for 'Lilliput' production, a height pattern between 20-25 cm would be appropriated for selection of plants with a pleasant and compact aspect. Earlier application of retardants, when main stem internodes are

Table 3 - Effects of growth retardants on leaf mass ratio (LMR), foliage and inflorescences harvest index (FIHI), inflorescences harvest index (IHI), inflorescence diameter and production cycle of 'Lilliput'.

\begin{tabular}{|c|c|c|c|c|c|}
\hline Treatment & Leaf mass ratio & $\begin{array}{c}\text { Foliage and inflorescences } \\
\text { harvest index }\end{array}$ & $\begin{array}{l}\text { Inflorescences } \\
\text { harvest index }\end{array}$ & $\begin{array}{c}\text { Inflorescence } \\
\text { diameter }\end{array}$ & Production cycle \\
\hline & - & $g^{-1}$ & 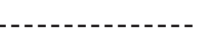 & $\mathrm{cm}$ & days \\
\hline Control & $0.23 \mathrm{~b}$ & $0.44 \mathrm{c}$ & $0.22 \mathrm{a}$ & $3.61 \mathrm{a}$ & $49.5 \mathrm{~b}$ \\
\hline $2.50 \mathrm{~g} \mathrm{~L}^{-1}$ daminozide & $0.26 \mathrm{ab}$ & $0.50 \mathrm{abc}$ & $0.25 \mathrm{a}$ & $3.58 \mathrm{a}$ & $53.1 \mathrm{ab}$ \\
\hline $3.75 \mathrm{~g} \mathrm{~L}^{-1}$ daminozide & $0.28 \mathrm{a}$ & $0.50 \mathrm{abc}$ & $0.22 \mathrm{a}$ & $3.55 \mathrm{a}$ & $53.1 \mathrm{ab}$ \\
\hline $5.00 \mathrm{~g} \mathrm{~L}^{-1}$ daminozide & $0.26 \mathrm{ab}$ & $0.51 \mathrm{ab}$ & $0.26 \mathrm{a}$ & $3.52 \mathrm{a}$ & $55.5 \mathrm{a}$ \\
\hline $0.50 \mathrm{mg}$ a.i. paclobutrazol & $0.25 \mathrm{ab}$ & $0.47 \mathrm{bc}$ & $0.22 \mathrm{a}$ & $3.60 \mathrm{a}$ & $50.5 \mathrm{~b}$ \\
\hline $0.75 \mathrm{mg}$ a.i. paclobutrazol & $0.26 \mathrm{ab}$ & $0.50 \mathrm{abc}$ & $0.24 \mathrm{a}$ & $3.53 \mathrm{a}$ & $51.8 \mathrm{ab}$ \\
\hline $1.00 \mathrm{mg}$ a.i. paclobutrazol & $0.28 \mathrm{a}$ & $0.52 \mathrm{ab}$ & $0.25 \mathrm{a}$ & $3.47 \mathrm{a}$ & $50.1 \mathrm{~b}$ \\
\hline $1.00 \mathrm{~g} \mathrm{~L}^{-1}$ chlormequat & $0.28 \mathrm{a}$ & $0.55 \mathrm{a}$ & $0.27 \mathrm{a}$ & $3.48 \mathrm{a}$ & $52.6 \mathrm{ab}$ \\
\hline Mean & 0.26 & 0.50 & 0.24 & 3.54 & 52.0 \\
\hline F test & $3.84 * *$ & $4.54 * *$ & $1.24^{\mathrm{ns}}$ & $0.35^{\mathrm{ns}}$ & $3.81 *$ \\
\hline HSD (Tukey's test) & 0.04 & 0.07 & 0.08 & 0.41 & 4.80 \\
\hline C.V $(\%)$ & 6.83 & 6.28 & 14.73 & 4.93 & 3.89 \\
\hline
\end{tabular}

Mean separation within columns by Tukey's multiple range test, $5 \%$ level; HSD $=$ honestly significant difference; $\mathrm{C} . \mathrm{V}=$ coefficient of

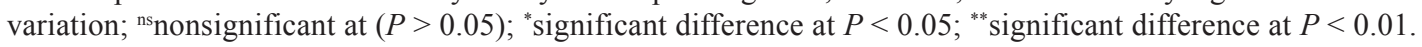



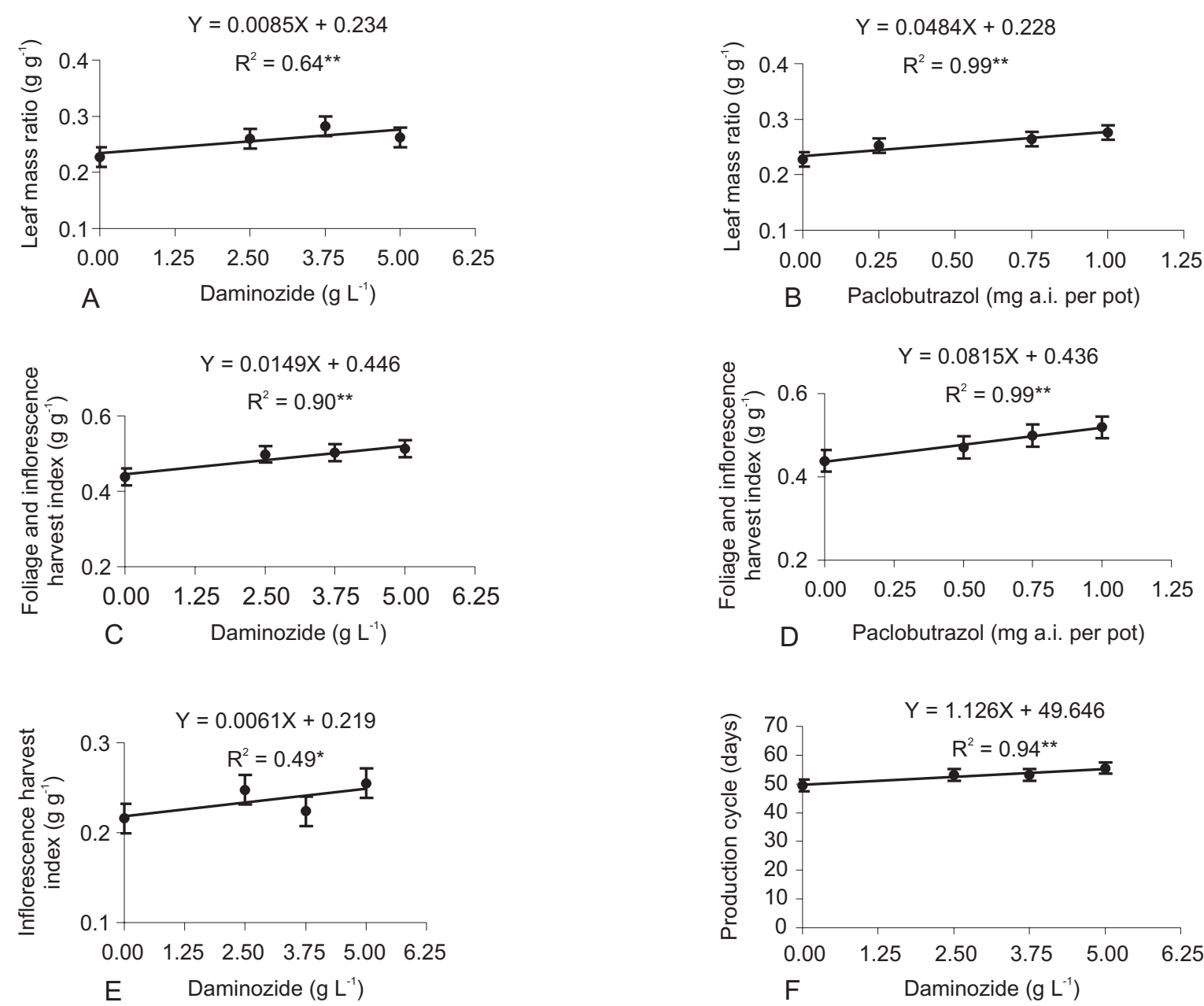

Figure 5 - Regression models of daminozide and paclobutrazol effects on leaf mass ratio (A-B), foliage and inflorescences harvest index $(C-D)$, inflorescences harvest index (E) and production cycle (F) of 'Lilliput'. Vertical bars represent the standart error of mean, $\mathrm{n}=4 ;$ *significant difference at $(P<0.05)$; **significant difference at $(P<0.01)$.

still shorter (plants with at least the thrird-leaf-pair completely expanded), could lead to a major control of elongation, not delaying floral transition. Under inductive flowering conditions, two-leaf-pair stage may correspond to the transition from vegetative to reproductive stage in zinnia (Kim et al., 1989). A second application of retardants may be necessary to help controlling of side branches elongation after reaching visible apical flower bud stage. This application may also contribute to the control of main stem internodes elongation up to the end of the production cycle, keeping retardants at growth inhibiting levels, since as reported by Sachs \& Hackett (1972), there is a gradual decay of retardants at the active sites, by metabolism.

Further studies should adjust suitable concentrations of retardants to an earlier developmental stage application and to a second application at visible apical flower bud stage, considering the cumulative effect of more than one application without delaying production cycle or causing phytotoxic symptoms and excessive growth suppression resulting in over-dwarfed plants.

\section{CONCLUSIONS}

Daminozide (2.5 and $3.75 \mathrm{~g} \mathrm{~L}^{-1}$ ), paclobutrazol $(0.5 ; 0.75$ and $1.0 \mathrm{mg}$ a.i. per pot) and chlormequat (1.0 $\left.\mathrm{g} \mathrm{L}^{-1}\right)$ supressed 'Lilliput' growth and did not affect flower diameter and production cycle, but plants were not short enough to meet market quality standards.

\section{ACKNOWLEDGMENT}

To CNPq for research grant of first, second and fourth authors.

\section{REFERENCES}

ANDERSEN, A.S.; ANDERSEN, L. Growth regulation as a necessary prerequesite for introduction of new plants. Acta Horticulturae, n.541, p.183-192, 2000.

ARMITAGE, A.M.; BASS, R.E.; CARLSON, W.H.; EWART, L.C. Control of plant height and flowering of Zinnia by photoperiod and growth retardants. HortScience, v.16, p.218-220, 1981.

BANKO, T.J.; STEFANI, M.A. Growth response of selected containergrown bedding plants to paclobutrazol, uniconazole, and daminozide. Journal of Environmental Horticulture, v.6, p.124-129, 1988. 
CATHEY, H.M. Comparative plant growth-retarding activities of ancymidol with ACPC, phosphon, chlormequat, and SADH on ornamental plant species. HortScience, v.10, p.204-216, 1975.

CHEN, C.L.; KEEVER, G.L.; DENEKE, C.F. Growth and flowering of triazole-treated zinnia (Zinnia elegans) and marigold (Tagetes erecta). Plant Growth Regulator Society of America Quarterly, v.21, p.169179, 1993.

CHRISTENSEN, O.V.; FRIIS, K. Research and development of unknown pot plants. Acta Horticulturae, n.205, p.33-37, 1987.

COX, D.A.; KEEVER, G.J. Paclobutrazol inhibits growth of zinnia and geranium. HortScience, v.23, p.1029-1030, 1988.

DAIE, J. Carbohydrate partitioning and metabolism in crops. Horticultural Reviews, v.7, p.69-108, 1985.

DAVIS, T.D.; STEFENS, G.L.; SANKHLA, N. Triazole plant growth regulators. Horticultural Reviews, v.10, p.63-105, 1988.

GRZESIK, M. Factors influencing the effectiveness of growth regulators in nursery production. Acta Horticulturae, n.251, p.371-375, 1989.

HALMANN, M. Synthetic plant growth regulators. Advances in Agronomy, v.43, p.47-105, 1990.

KIM, H.Y.; SUZUKI, Y. Changes in assimilated ${ }^{13} \mathrm{C}$ distribution and soluble acid invertase activity of Zinnia elegans induced by uniconazol, an inhibitor of gibberellin biosynthesis. Plant Physiology, v.90, p.316-321, 1989.

KIM, H.Y.; ABE, T.; WATANABE, H.; SUZUKI, Y. Changes in flower bud development of Zinnia elegans Jacq. as influenced by growth retardant S-07. Journal of Horticultural Science, v.64, p.81-89, 1989.

KIM, H.Y.; WATANABE, H.; SUZUKI, Y. Effect of growth retardant uniconazol on the floral formation of Zinnia elegans Jacq. Journal of the Japanese Society for Horticultural Science, v.61, p.603-608, 1992.
KORANSKI, D.S.; McCOWN, B.H.; STRUCKMEYER, B.E.; BECK, G.E. Gibberellin-growth interactions on growth and flowering of Clerodendrum thomsoniae. Physiologia Plantarum, v.45, p.88-92, 1979.

LATIMER, J.C. Growth retardants affect landscape performance of Zinnia, Impatiens and Marigold. HortScience, v.26, p.557-560, 1991.

LOVELL, P.H. Translocation of photosynthesis in tall and dwarf varieties of pea, Pisum sativum. Physiologia Plantarum, v.25, p.382-385, 1971.

METCALF, H.N.; SHARMA, J.N. Germ plasm resources of the genus Zinnia L. Economic Botany, v.25, p.169-181, 1971.

MIYAJIMA, D.; NAKAYAMA, M. Analysis of Zinnia capitulum composition. Journal of the American Society for Horticultural Science, v.119, p.683-686, 1994.

MULLIGAN, D.R.; PATRICK, J.W. Gibberellic acid promoted transport of assimilates in stems of Phaseolus vulgaris L. localised versus remote site(s) of action. Planta, v.145, p.233-238, 1979.

PEREIRA, A.R.; MACHADO, E.C. Análise quantitativa do crescimento de comunidades vegetais. Campinas: IAC, 1987.33p. (Boletim Técnico, 114).

PINTO, A.C.R. Efeitos de tamanho de vaso, sistema de condução e reguladores vegetais no desenvolvimento e na qualidade de cultivares de zínia. Jaboticabal: UNESP/FCAV, 2003. (Tese - Doutorado).

SACHS, R.M.; HACKETT, W.P. Chemical inhibition of plant height. HortScience, v.72, p.440-447, 1972.

Received August 09, 2004

Accepted May 19, 2005 